\title{
O Rádio como Suporte Musical-Composicional - em busca de ferramentas para notações fonéticas e processos criativos para performance radiofônica
}

\author{
Lucas Rodrigues Ferreira (IC)
}

\section{Resumo}

Neste trabalho formalizamos ferramentas que permitem a composição de trabalhos radiofônicos e de performance através de um pensamento musical. Para isso partimos da análise da peça Words and Music, de Samuel Beckett, correlacionando seus usos de gestualidades, repetições, da escuta reduzida, e dos usos possíveis da voz em peças radiofônicas a obras e conceitos do repertório musical do século XX.

Palavras Chave: Rádio-Arte, Composição, Rádio.

\section{Introdução}

Neste trabalho formalizamos ferramentas que permitem a composição de trabalhos radiofônicos e de performance através de um pensamento musical. Para isso partimos da análise da peça Words and Music, de Samuel Beckett, correlacionando seus usos de gestualidades, repetições, da escuta reduzida a partir de Michel Chion, e dos usos possíveis da voz em peças radiofônicas a obras e conceitos do repertório musical do século $X X$.

\section{Resultados e Discussão}

Interessa a este trabalho uma dialética entre som e significado, e a identificação e formalização de ferramentas de trabalho que se registrem em um campo artístico misto, localizado entre técnicas de composição musical derivadas das experimentações sonoras da segunda metade do século $X X$, principalmente a abordagem dos compositores da Escola de Nova York sobre repetição, processos iterativos e jogos de improvisação, E o teatro construido não sobre a palavra, mas sobre o som do dramaturgo Irlandês Samuel Beckett, especificamente a peça radiofônica Words and Music, de 1961, que analisaremos frente a referências diretas, incorporando ainda, para enriquecimento da análise, referências a outras peças do mesmo dramaturgo que refletem a profundidade das mudanças que o trabalho para meios tecnológicos conflagrou em sua obra. É caro ainda para as análises e desenvolvimento da pesquisa o conceito de Escuta Reduzida que permeia os escritos do pioneiro da músique concréte francesa Pierre Schaeffer, aqui utilizado na acepção definida por Michel Chion em seu Guide des Objets Sonore. Este último nos permite realizar um paralelos em termos musicais às estruturas repetitivas, que, por suas modularidades, esvaem o signifado e permitem a escuta sonora, não-semântica, do texto.

Esclarecidos por esta análise, então, é proposta a elaboração de um texto teatral-radiofônico que se utilize de processos extraídos da composição musical para a sua composição, para ser realizado em uma obra performática para a voz de um ator e acompanhamento instrumental de um pianista.

\section{Conclusões}

Concluímos com diversas ferramentas que nos permitem a experimentação sonora no contexto de composição de peças musicais radiofônicas, a partir do pensamento da linguagem como material sonoro. Para este ponto de vista contribui o conceito de "escuta reduzida" segundo Michel Chion, recontextualizado aqui em referência às estruturas cíclicas aplicadas por Beckett em seus processos de escritura. Desenvolvemos então modos de trabalho que são igualmente aplicáveis ao som e ao texto, uma vez que consideramos aqui o texto como som que se esvai de sua significância através da repetição ad nauseam.

\section{Agradecimentos}

Agradeço meu orientador Prof. Dr. José Augusto Mannis, a coorientadora Janete El Haouli, o ator Pedro Carvalho, o pianista Giancarlo Staffetti, e Beatriz Moura.

Este trabalho foi possível graças ao fomento do $\mathrm{PIBIC/CNPq}$.

BECKETT, Samuel: The Complete Dramatic Worls; Faber and Faber, Londres, Reino Unido, 1986.

CHION, Michel: Guide to Sound Objects; Columbia University Press, New York, EUA, 1983. 